\title{
MODEL PEMBELAJARAN KARAKTER PELAUT
}

\author{
Wegig Pratama \\ Akademi Maritim Yogyakarta \\ wegigpratama@gmail.com \\ Pardjono \\ Fakultas Teknik Universitas Negeri Yogyakarta \\ pardjono@uny.ac.id
}

\begin{abstract}
Abstrak
Penelitian ini bertujuan untuk menghasilkan: (1) deskripsi tentang nilai-nilai karakter pelaut yang sudah dikembangkan pada taruna di Pertikepel; (2) deskripsi tentang nilai-nilai karakter pelaut yang menjadi tuntutan industri pelayaran internasional; (3) model pembelajaran karakter pelaut yang efektif untuk diterapkan pada taruna Pertikepel. Penelitian ini merupakan penelitian dan pengembangan yang mengacu pada model Research \& Development Richey dan Klein. Tahapan penelitian ini adalah: (1) pengembangan model needs assessment dan draf model (2) validasi model internal menggunakan metode FGD dan expert review, serta validasi model eksternal menggunakan metode quasi experimental dengan one group pretest posttest design dari Isaac dan Michael. Hasil penelitian: (1) nilai karakter pelaut yang sudah dikembangkan pada taruna Pertikepel adalah disiplin; (2) nilai karakter pelaut yang seharusnya dikembangkan pada taruna Pertikepel adalah tanggung jawab, kepercayaan diri, etos kerja, pemecahan masalah, dan kerja sama; (3) efektifitas model Co-Prol dilihat dari perkembangan trend nilai karakter taruna perminggunya selama 16 minggu, didapatkan efektif.
\end{abstract}

Kata kunci: karakter pelaut, co-prol, pertikepel

\section{INSTRUCTIONAL MODEL OF SEAFARERS' CHARACTER}

\begin{abstract}
The objectives of this research were to produce: (1) the description of values of seafarers' character had been developed for the students of Pertikepel; (2) the description of the values of seafarers' character required by international maritime industry; (3) the effective seafarers' character instructional model applied for the students of Pertikepel. This study used a Research and Development Model proposed by Richey \& Klein. The research involved the following steps: (1) developing the model of need assessment and draft, (2) validating the internal model using FGD method and expert review, and validating the external model using quasi experimental method withone group pretest posttest design proposed by Isaac and Michael. The results of the research showed that: (1) discipline was the value of seafarers' character which had been developed for the students of Pertikepel; (2) the values of seafarers' character should be developed for the students of maritime higher education were responsibility, self confidence, work ethic, problem solving, and cooperativeness; (3) the Co-Prol model was effective since there was the development of the weekly increasing trend on the values of character, starting from first week until sixteenth week.
\end{abstract}

Keywords: seafarers' character, co-prol, pertikepel 


\section{PENDAHULUAN}

Peluang puluhan ribu kesempatan kerja sebagai perwira pelaut di kapal-kapal internasional belum dapat dimanfaatkan dengan baik, karena kualitas lulusan belum sesuai dengan permintaan pasar kerja internasional (Majalah Maritim nomor 476, 2007). Proses penyiapan sumber daya manusia untuk mengisi kebutuhan pelaut sesuai dengan kebutuhan pasar kerja industri pelayaran internasional harus memenuhi kualifikasi sebagaimana yang dipersyaratkan International Maritime Organization (IMO) melalui STCW 1978 beserta amandemennya. Salah satu persyaratannya sebagaimana tertuang pada Peraturan Pemerintah RI Nomor 7 Tahun 2000 pada Bab I ketentuan umum pasal (3), Pelaut adalah seseorang wajib memiliki kualifikasi keahlian/Certificate of Competency $(\mathrm{CoC})$ dan kualifikasi keterampilan/Certification of Proficiency (CoP) sebagai awak kapal. Kedua sertifikat tersebut dikeluarkan oleh Direktorat Jendral Perhubungan Laut (Ditjen Hubla) sebagai perwakilan administrasi IMO di Indonesia. Khusus untuk mendapatkan $\mathrm{CoC}$ seorang taruna harus mengikuti pendidikan di Perguruan Tinggi Kepelautan (Pertikepel).

Penelitian yang dilakukan oleh Pratama (2010, p. 142) dengan judul "Evaluasi Implementasi QSS berbasis IMO di Akademi Maritim Yogyakarta (AMY)" menghasilkan temuan bahwa capaian rerata implementasi QSS sebesar $88,26 \%$, sudah dapat dikatakan memenuhi standar minimal secara subtantif bila dibandingkan dengan standar. Namun kenyataannya tidak semua lulusan AMY dapat terserap di industri pelayaran Internasional hal ini terjadi karena adanya komponen kompetensi yang harus dimiliki seorang pelaut selain pengetahuan dan keterampilan diantaranya adalah karakter (Elenora, 2009, p. 3).

Permasalahan yang terjadi pada Pertikepel adalah belum teridentifikasinya nilainilai karakter pelaut yang sudah dikembangkan pada taruna di Pertikepel, dan nilai-nilai karakter pelaut yang seharusnya dikembangkan untuk memenuhi tuntutan industri pelayaran internasional. Selanjutnya, sampai sejauh ini juga belum ada model pembelajaran nilai-nilai karakter bagi pelaut yang efektif bagi taruna Pertikepel. Kegiatan belajar mengajar di Pertikepel pada saat ini belum mendukung pengembangan karakter lulusan dan masih menekankan pada pembelajaran yang output-nya mengarah pada kompetensi mata kuliah sesuai dengan standar. Implementasi pengembangan karakter pada Pertikepel masih terbatas pada budaya kampus dan kelompok Mata Kuliah Pengembangan Kepribadian (MPK). Hal ini tercermin dalam pengamatan pada beberapa Pertikepel, salah satunya dilakukan interview dengan Quality Management Representative (QMR) AMY. Bertolak dari fakta tersebut, dapat digarisbawahi bahwa aspek karakter sangat berperan dalam menunjang kesuksesan lulusan Pertikepel agar dapat bekerja di industri pelayaran internasional. Sementara itu dalam kegiatan pembelajaran di Pertikepel belum memberikan kesempatan untuk mengembangkan dan memupuk karakter taruna. Zuchdi, et al. (2010, p. 51) menyatakan bahwa pendidikan karakter di perguruan tinggi dapat dilaksanakan melalui perkuliahan, pelatihan dan pengembangan kultur.

Karakter merupakan ciri khas seseorang yang mengandung nilai, kemampuan, kapasitas moral, dan ketegaran dalam menghadapi kesulitan dan tantangan yang dapat dibentuk melalui pengaruh lingkungan. Karena itu bidang garapan pembentukan karakter dapat melalui pembentukan tingkah laku (behavior) seseorang. Pemerintah Republik Indonesia dalam Kebijakan Nasional Pembangunan Karakter Bangsa tahun 2010 - 2025 (2010, p. 7), mendefinisikan bahwa karakter merupakan ciri khas seseorang atau sekelompok orang yang mengandung nilai, kemampuan, kapasitas moral, dan ketegaran dalam menghadapi kesulitan dan tantangan. Kenyataannya pada saat ini belum semua jenjang pendidikan di Indonesia khususnya pada jenjang pendidikan vokasi, yang mengadopsi pendidikan karakter pada kurikulumnya khususnya pada Pertikepel. Berdasarkan penjelasan tersebut, untuk memenuhi amanah Undang-Undang Nomor 20 Tahun 2003 tersebut, Pertikepel perlu mengembangkan karakter bagi tarunanya.

Implementasi pendidikan karakter dalam perspektif budaya akademik, pendidikan karakter tidak berdiri sendiri, namun ditempatkan secara asimilatif, hal tersebut dapat diartikan bahwa pendidikan karakter diimplementasikan dengan cara digabungkan dengan pendidikan akademik (keilmuan/keterampilan) kemudian dapat memberikan pemahaman baru. Pemahaman baru ini dapat diartikan, yaitu jika lulusan pendidikan tinggi ditempatkan 
dalam dunia kerja, kemampuan intelektualitasnya tertumpu pada nilai-nilai dasar karakter (Ditjen Dikti, 2011, p. 50). Oleh karena itu, pengembangan karakter bagi taruna di Pertikepel perlu dilakukan penelitiandengan membuat model pembelajaran. Untuk mempersiapkan lulusan yang memenuhi kualitas dan sesuai harapan merupakan langkah penting yang harus dilakukan.

Hasil FGD yang melibatkan pelaut dan manajemen pelayaran ditemukan 17 nilai karakter yang harus dimiliki pelaut meliputi: disiplin, tangguh, komitmen, tanggung jawab, kreativitas, integritas, kepercayaan diri, kerja sama, keberanian, keuletan, etos kerja, ketabahan, mudah beradaptasi, mandiri, pemecahan masalah, rasa humor/sense of humor, dan kewaspadaan. Zuchdi, et al. (2010, p.41) melakukan pengintegrasian pendidikan karakter di Universitas Negeri Yogyakarta (UNY) melalui salah satu caranya adalah lesson study. Hasil pendidikan karakter melalui cara tersebut, menunjukan hasil yang positif. Nilai-nilai target yang ditetapkan hampir seluruhnya terealisasi dalam perkuliahan.

Teori belajar yang dinilai relevan untuk mengembangkan pembelajaran karakter di Pertikepel adalah teori belajar Behavioristik dan teori belajar Konstruktivistik. Sedangkan dalam teori, belajar dengan strategi pembiasaan, dikenal dengan operant conditioning, adalah membiasakan peserta didik untuk ber-perilaku terpuji seperti: disiplin, giat belajar, bekerja keras, jujur, tanggungjawab, bekerja sama, toleransi dan lain-lain, Gunawan (2012, p. 94). Model pembelajaran yang biasa digunakan, antara lain: keteladanan, pembelajaran kontekstual, problem based learning, cooperative learning. Terkait dengan banyak model pembelajaran yang terus berkembang, pada penelitian ini difokuskan pada model yang dipandang relevan dengan tujuan penelitian dan pengembangan, yaitu pendekatan cooperative learning dan problem based learning yang dinamakan Co-Prol. Hal ini sejalan dengan Yuso, et al. (2011, p. 373) yang telah mengembangkan model pembelajaran Cooperative Problem-Based Learning (CPBL) pada jurusan teknik. Terdapat tiga fase pembelajaran pada model CPBL ini yaitu fase aktivitas belajar, fase mengajar dan fase penugasan. Selain itu, model CPBL yang praktis ini cocok diberikan untuk pembelajaran pada jurusan teknik. Hasil penelitian ini sangat relevan dengan model pembelajaran Co-Prol yang dikembangkan pada penelitian ini.

Berdasarkan paparan di atas diperlukan penelitian untuk menemukan: (1) deskripsi tentang nilai-nilai karakter pelaut yang sudah dikembangkan pada taruna di Pertikepel, (2) deskripsi tentang nilai-nilai karakter pelaut apa sajakah yang seharusnya dikembangkan untuk memenuhi menjadi tuntutan industri pelayaran internasional, dan (3) model pembelajaran karakter pelaut yang efektif untuk diterapkan pada taruna Pertikepel.

\section{METODE PENELITIAN}

Model pengembangan dalam penelitian ini mengacu pada model Research and Development (R\&D) dari Richey \& Klein (2009, p. 8), dengan tahapan meliputi: (1) pengembangan model, dan (2) validasi model, yang dibagi dua yakni, validasi internal dan validasi eksternal/ujicoba.Pada tahapan pengembangan model diawali dengan needs assessment yang dilanjutkan dengan pembuatan draf model yang nantinya digunakan sebagai rujukan pengembangan model pembelajaran karakter pelaut. Needs Assessment, dilakukan pengumpulan data dengan pendekatan kuantitatif dengan metode survey, data dikumpulkan dengan menggunakan angket dilengkapi dengan observasi dan wawancara dan setelah didapatkan hasil needs assessment, dirancang draf awal model pembelajaran dengan mengacu pada model pembelajaran yang sudah ada di Pertikepel. Hasil dari rancangan ini merupakan suatu desain atau model hipotetik.

Setelah didapatkan rancangan model hipotetik kemudian disusun buku panduan. Isi buku panduan meliputi: action plan, rencana pelaksanaan pembelajaran, bahan ajar, dan format evaluasi yang berupa lembar observasi. Sedangkan untuk tahapan validasi model, dilakukan uji validasi model secara internal dan eksternal. Pertama, uji validasi internal melalui dua kegiatan, yakni FGD dan dilakukan expert review oleh para ahli atau pakar yang meliputi: (1) ahli evaluasi pendidikan (2) ahli pendidikan karakter, dan (3) ahli bidang pendidikan vokasi. Kedua, uji validasi eksternal/ uji coba, validasi ini dilakukan dengan menggunakan metode Experimental, dengan onegroup - pretest - posttest design dari Isaac dan Michael (1981, p. 64). 
Tempat yang dipilih untuk uji coba model Co-Prol penelitian ini adalah AMY dan Sekolah Tinggi Maritim (STIMART) AMNI Semarang. Penelitian dilaksanakan selama 18 bulan. Populasi yang dipilih dalam penelitian ini adalah 10 Pertikepel, yang terdiri dari 3 Pertikepel negeri dan 7 Pertikepel swasta dan telah mendapatkan Approval dari Ditjen Hubla. Sampel penelitian ini ditentukan dengan menggunakan teknik purposive sampling, sampel yang terpilih pada penelitian ini adalah 7 Pertikepel swasta di Indonesia yang telah mendapatkan Approval dari Ditjen Hubla. Selanjutnya subjek penelitian ini secara random terpilih: (1) Akademi Maritim Indonesia Medan, (2) Akademi Maritim Indonesia Veteran Makasar, (3) STIMART-AMNI Semarang, dan (4) AMY Yogyakarta.Subjek uji coba penelitian ini adalah taruna Prodi Teknika yang pada saat dilakukan uji coba duduk di semester 2 tahun akademik 2013/ 2014. Penentuan subjek uji coba dengan $p u$ rposive sampling, didapatkan AMY sebanyak 11 taruna dan STIMART-AMNI sebanyak 10 taruna. Sedangkan waktu uji coba selama enam belas kali pertemuan (satu semester). Mata kuliah yang dijadikan sasaran implementasi model pembelajaran adalah mata kuliah Mesin Penggerak Utama II (MPU II).

Informasi atau data dalam penelitian ini didapatkan dengan menggunakan empat instrumen. Instrumen pertama terkait dengan kepentingan pengembangan model. Instrumen kedua digunakan untuk melengkapi instrumen pertama sebelumnya. Instrumen ketiga digunakan untuk menguji keefektifan model, dan instrumen keempat digunakan untuk merefleksi diri taruna. Untuk mengetahui efektifitas model pembelajaran dilakukan dengan dua cara. Pertama, efektifitas model pembelajaran ditentukan berdasarkan data pengamatan yang dituangkan dalam lembar observasi oleh observer. Kedua, efektifitas model pembelajaran dilihat dari subjek uji coba/taruna dengan melakukan refleksi diri, sebelum perlakuan dan sesudah perlakukan melalui kuisioner yang telah disediakan.

\section{HASIL PENELITIAN DAN PEMBAHASAN}

Data hasil penelitian dan pengembangan ini disusun berdasarkan tahapan penelitan yang sudah dilaksanakan yaitu, tahapan pengembangan dan tahapan validasi dan uji coba model. Selanjutnya tahapan tersebut dapat dijelaskan sebagai berikut.

\section{Tahap Pengembangan Model}

Pada tahap pengembangan dilakukan needs assesment, pembuatan draf model, penyusunan panduan model, dan validasi model. Sebelum melakukan kegiatan needs assessment terlebih dahulu dilakukan kegiatan FGD. Materi yang dipergunakan dalam FGD adalah hasil wawancara dengan teman sejawat/dosen AMY yang mempunyai latar belakang sebagai pelaut dan sumber lain.Hasil FGD diperoleh 17 nilai karakter pelaut yang dibutuh industri pelayaran internasional. Kemudian dari 17 nilai karakter tersebut terpilih 6 nilai karakter pelaut yang dijadikan sebagai nilai target karakter pelaut pada penelitian yakni disiplin, tanggung jawab, etos kerja, kepercayaan diri, pemecahan masalah, dan kerja sama.

Untuk mendapatkan nilai-nilai karakter pelaut apa saja yang sudah diimplementasikan dari ke 17 temuan dari FGD, maka dilakukan kegiatan needs assesment di Pertikepel baik melalui pembelajaran maupun kultur kampus. Pelaksanaan needs assessment ini menggunakan pendekatan kuantitatif dengan metode survei.

Hasil needs assesment menujukkan bahwa: (1) nilai karakter disiplin telah diimplementasikan secara penuh $(100 \%)$ baik melalui KBM maupun budaya kampus; (2) nilai karakter tanggung jawab telah dimplementasikan melalui KBM 89,58 \%, melalui budaya kampus 97,92 \%, dan rata-rata 93,75\%; (3) nilai karakter kepercayaan diri telah diimplementasikan melalui KBM 41,67 \%, melalui budaya kampus sebesar 33,33\%, dan rata-rata 37,50\%; (4) nilai karakter etos kerja telah diimplementasikan melalui KBM sebesar $75 \%$, melalui budaya kampus sebesar $83,33 \%$, dan rata-rata $79,17 \%$; (5) nilai Karakter Pemecahan Masalah melalui KBM telah diimplementasikan sebesar $35,42 \%$, melalui budaya kampus sebesar $45,83 \%$, dan rata-rata 40,62\%; (6) nilai Karakter Kerja sama melalui KBM telah diimplementasikan sebesar $43,75 \%$, melalui budaya kampus sebesar $52,08 \%$, dan rata-rata $47,92 \%$.

Berdasarkan hasil FGD tentang nilainilai karakter pelaut yang dibutuhkan industri pelayaran internasional, needs assessment dan hasil survei di institusi Pertikepel di In- 
donesia, diketahui masih terdapat kesenjangan. Kesenjangan masih ditemukan pada nilainilai target pendidikan karakter pelaut: (1) tanggung jawab, (2) percaya diri, (3) etos kerja, (4) pemecahan masalah, dan (5) kerja sama. Dengan tidak bermaksud mengesampingkan pengembangan pada nilai-nilai karakter pelaut lainnya, kesenjangan tersebut merupakan permasalahan yang perlu diatasi agar nilai-nilai karakter pelaut yang dibutuhkan oleh industri pelayaran internasional sesuai dengan yang dibiasakan di Pertikepel.

Untuk melengkapi informasi yang telah diperoleh dari data tersebut, dilakukan studi lapangan ke Akademi Maritim Indonesia (AMI) Medan, AMY dan STIMART-AMNI Semarang. Dari hasil pengamatan dan wawancara terungkap bahwa kegiatan pembelajaran belum sepenuhnya menggunakan model pembelajaran yang mengembangkan nilainilai karakter pelaut. Model pembelajaran yang sering digunakan masih didominasi pembelajaran yang berorientasi pada pencapaian standar kompetensi mata kuliah yang diajarkan, dan masih kurang memperhatikan nilai-nilai karakter pelaut.

Melalui wawancara dan pengamatan terungkap bahwa secara umum pelaksanaan pembelajaran di kelas dan di laboratorium yang selama ini diterapkan di Pertikepel, sebagai berikut: (1) dosen memberikan materi teori melalui penjelasan awal mengenai ruang lingkup materi kuliah; (2) taruna dikelompokan dengan jumlah 3 sampai dengan 4 orang per kelompok; (3) secara kelompok taruna membuat makalah sesuai topik kuliah; (4) sesuai urutan kelompoknya, taruna melakukan presentasi sesuai topik masing-masing di kelas; (5) setelah melaksanakan presentasi, melakukan revisi makalah dengan memperhatikan masukan hasil diskusi kelas dan dosen kemudian baru di serahkan ke dosen untuk dinilai; (6) setelah perkuliahan minamal 6 kali (6 Minggu) diadakan Ujian tengah semester; (7) pada waktu pelaksanaan praktek dosen melakukan penilaian; dan (8) diakhir perkuliahan dilakukan ujian akhir semester.

Dari uraian tersebut dapat diketahui bahwa selama ini proses pembelajaran yang merupakan gabungan teori dan praktik laboratorium belum sepenuhnya memperhatikan pengembangan nilai-nilai karakter pelaut bagi taruna. Kalaupun itu sudah ada, sifatnya masih spontan, belum secara terstuktur. Oleh karena itu, peningkatan nilai-nilai karakter pelaut bagi taruna sebagai hasil belajar belum diketahui secara pasti.

Kenyataan yang ada ini minimal terdapat dua permasalahan mendasar, yaitu: (1) tidak diketahuinya nilai-nilai karakter pelaut apa sajakah yang prioritas dikembangkan sesuai dengan tuntutan dunia kerja, dan (2) tidak diketahuinya sejauh mana keefektifan model pembelajaran yang sudah diterapkan kepada taruna. Dengan demikian dapat dikatakan bahwa ada kesenjangan antara nilainilai karakter pelaut yang diharapkan oleh industri pelayaran internasional dengan nilainilai karakter pelaut yang sudah dikembangkan melalui pembelajaran maupun kultur kampus pada pendidikan tinggi kepelautan. Kesenjangan ini ditunjukan pada nilai-nilai karakter pelaut tanggung jawab, kepercayaan diri, etos kerja, pemecahan masalah, dan kerja sama yang selanjutnya lima nilai karakter pelaut tersebut ditetapkan sebagai nilai-nilai target pendidikan karakter pelaut pada penelitian ini. Berdasarkan kondisi tersebut, maka perlu merancang model pembelajaran karakter melalui mata kuliah teori dan praktik di kelas maupun laboratorium.

Berdasarkan hasil yang diperoleh dari kesenjangan yang ditemukan melalui needs assessment, hasil wawancara dan pengamatan, peneliti mengembangkan model pembelajaran dengan mengoptimalkan penggunaan strategi pembelajaran, agar keefektifan pembelajaran nilai-nilai karakter pelaut dapat tercapai, dan diyakini dapat menyelesaikan kesenjangan yang terjadi. Strategi pembelajaran yang dikembangkan merupakan pengembangan pembelajaran sebelumnya, yang menggunakan pendekatan kooperatif dan pemecahan masalah. Rancangan model yang dikembangkan berlandaskan pada prinsip Cooperative Learning dan Problem Based Learning, yang selanjutnya diberi nama Co-Prol.

Model Co-Prol merupakan model pembelajaran yang dilakukan sebagai usaha meningkatkan kualitas pembelajaran secara terus menerus ke arah yang lebih baik yang dilakukan secara terprogram dan terevaluasi dalam rangka membangun nilai-nilai karakter taruna. Konsep ini sejalan dengan definisi belajar yang dikemukakan oleh Hergenhahn dan Olson (2008; pp. 2-3) mendifinisikan belajar adalah perubahan perilaku atau potensi perilaku yang relatif permanen yang berasal dari 
pengalaman. Pendapat tersebut diperjelas oleh Morgan (Rahyubi, 2012, p. 5), perubahan tingkah laku sebagai hasil belajar meliputi tiga domain tahapan, yakni: (1) tahap kognitif, peserta didik dituntut untuk mengingat, memahami, mengklarifikasi, dan menganalisis tentang apa yang telah dipelajari; (2) tahap afektif, diharapkan siswa mampu menguasai tentang sikap, minat serta nilai-nilai positif lainnya; (3) kemudian tahap ketiga yang bersifat psikomotor menekankan kepada tujuan agar siswa di samping mengerti, memahami, tetapi juga harus mampu menguasai dan melakukan aktivitas keterampilan. Dua pendapat tersebut menyiratkan dua makna. Pertama, bahwa belajar merupakan suatu usaha untuk mencapai tujuan tertentu yaitu untuk mendapatkan perubahan tingkah laku yang relatif permanen. Kedua, perubahan tingkah laku yang terjadi melalui tiga tahapan yakni tahap kognitif, afektif dan psikomotorik.

Terkait dengan definisi tersebut, model Co-Prol merupakan salah satu usaha untuk mencapai perubahan tingkah laku, khususnya tingkah laku yang ditunjukkan dalam bentuk perilaku sehari-hari. Dengan demikian, perubahan tingkah laku taruna yang ditunjukkan sehari-hari itu dipandang sebagai hasil belajar.

Model pembelajaran Co-Prol mengacu pada teori behaviorisme, yakni teori perkembangan perilaku yang dapat diukur dan diamati dan dihasilkan oleh respon belajar terhadap stimulus. Dalam aliran ini stimulus berupa lingkungan yang dikondisikan dengan menerapkan model Co-Prol, sedangkan respons berupa perubahan tingkah laku seharihari yang terjadi pada taruna.

Menurut Morse \& Kelleher (Schunk, 2012, p. 136) langkah-langkah dalam pembentukan perilaku dalam proses pembelajaran adalah: (1) mengidentifikasi perilaku awal; (2) mengidentifikasi perilaku yang diharapkan; (3) mengidentifikasi potensi-potensi penguat dalam lingkungan taruna; (4) membagi perilaku yang dituju menjadi langkah-langkah kecil yang harus dikuasai secara berurutan, dan (5) menggerakan taruna dari perilaku awal menuju perilaku yang diinginkan secara bertahap sesuai penguatan masing-masing perkiraan. Berdasarkan langkah-langkah tersebut, hampir semua hal itu telah diimplementasikan dengan baik dalam model Co-Prol.

Selanjutnya model Co-Prol disamping relevan terhadap teori behaviorisme juga sa- ngat relevan dengan teori konstruktivisme, hal tersebut didasarkan pada pemikiran bahwa taruna memperoleh pengetahuan karena keaktifan mereka sendiri. Konsep pembelajaran menurut teori konstrukstivisme menurut Rusmono (2012, p. 16) adalah suatu pembelajaran yang mengutamakan taruna untuk membangun sendiri pengetahuannya. Oleh sebab itu kegiatan pembelajaran harus dirancang dan dikelola sedemikian rupa sehingga taruna mampu mengorganisasikan pengalamannya sendiri menjadi pengetahuan yang bermakna. Jadi dalam konstruktivisme taruna berperan penting dalam membangun pengetahuannya sendiri melalui kebebasan dan keaktifan belajar untuk menguasai dan menemukan sendiri pengetahuan-pengetahuan yang dibutuhkan dalam kehidupan.

Rancangan model diterapkan pada mata kuliah MPU II beban studi 2 sks yang terbagi atas 1 sks teori dan 1 sks praktik laboratorium. Oleh karena itu pengembangan nilai-nilai karakter perlu didasarkan pada pokok-pokok pikiran bahwa hasil proses pembelajaran selain berupa penguasaan terhadap kompetensi mata kuliah, juga berupa nilai-nilai karakter pelaut yang secara terintegrasi diperoleh melalui proses pembelajaran taruna. Selanjutnya untuk memenuhi hal tersebut diatas diperlukan pengembangan pembelajaran dengan memilih strategi belajar yang diyakini mampu membantu taruna memiliki nilai-nilai karakter pelaut yang dibutuhan dunia kerja. Secara khusus, dengan kompetensi mata kuliah dan nilai-nilai karakter pelaut yang diperoleh taruna melalui pengalaman belajar diharapkan dapat memecahkan masalah dengan menggunakan pengetahuan dan ketrampilan yang telah dipelajarinya.

Implementasi pada setiap kegiatan pembelajaran yang dilakukan mingguan dirancang adanya pengembangan nilai-nilai target pendidikan karakter pelaut. Ada kalanya pada satu pertemuan dimuati empat nilai karakter pelaut, tetapi rata-rata dimuati dengan 5 nilai karakter pelaut. Muatan nilai karakter pelaut disesuaikan dengan bentuk kegiatan belajar yang dilakukan pada saat itu. Adapun action plan yang disusun untuk setiap tahapan pembelajaran dimulai dari pertemuan pertama sampai dengan selesai.

Untuk memudahkan pelaksanaan model pembelajaran Co-Prol, maka dikembangkan pula pedoman pelaksanaan dalam bentuk 
buku panduan model. Buku panduan memuat tentang Rencana Pelaksanaan Pembelajaran yang berisi mulai pokok bahasan sampai dengan bentuk evaluasinya. Di bagian akhir buku panduan dilengkapi Lembar Observasi implementasi nilai target pendidikan karakter taruna yang nantinya digunakan observer untuk menilai karakter yang dikembangkan. Untuk membangun keyakinan bahwa model yang dibangun layak digunakan, maka tahapan selanjutnya adalah melakukan validasi. Validasi model dilakukan agar model dan buku panduan yang telah dirancang mendapat masukan dan kritikan yang sifatnya mem- bangun. Model yang berhasil dikembangakan ditunjukkan pada Gambar 1. dan Gambar 2.

Model Co-Prol kedua adalah pertemuan kelima sampai kelimabelas merupakan kegiatan praktik di laboratorium Mesin Utama yang dilakukan secara berulang. Pada model pembelajaran karakter pelaut ini juga dikembangkan lima karakter target yang sama dengan model pertama, kecuali pada kegiatan block test dipertemuan kesepuluh dan kelimabelas nilai karakter pelaut target kerja sama tidak diikutkan dalam penilaian. Gambar 2 model Co-Prol kedua.

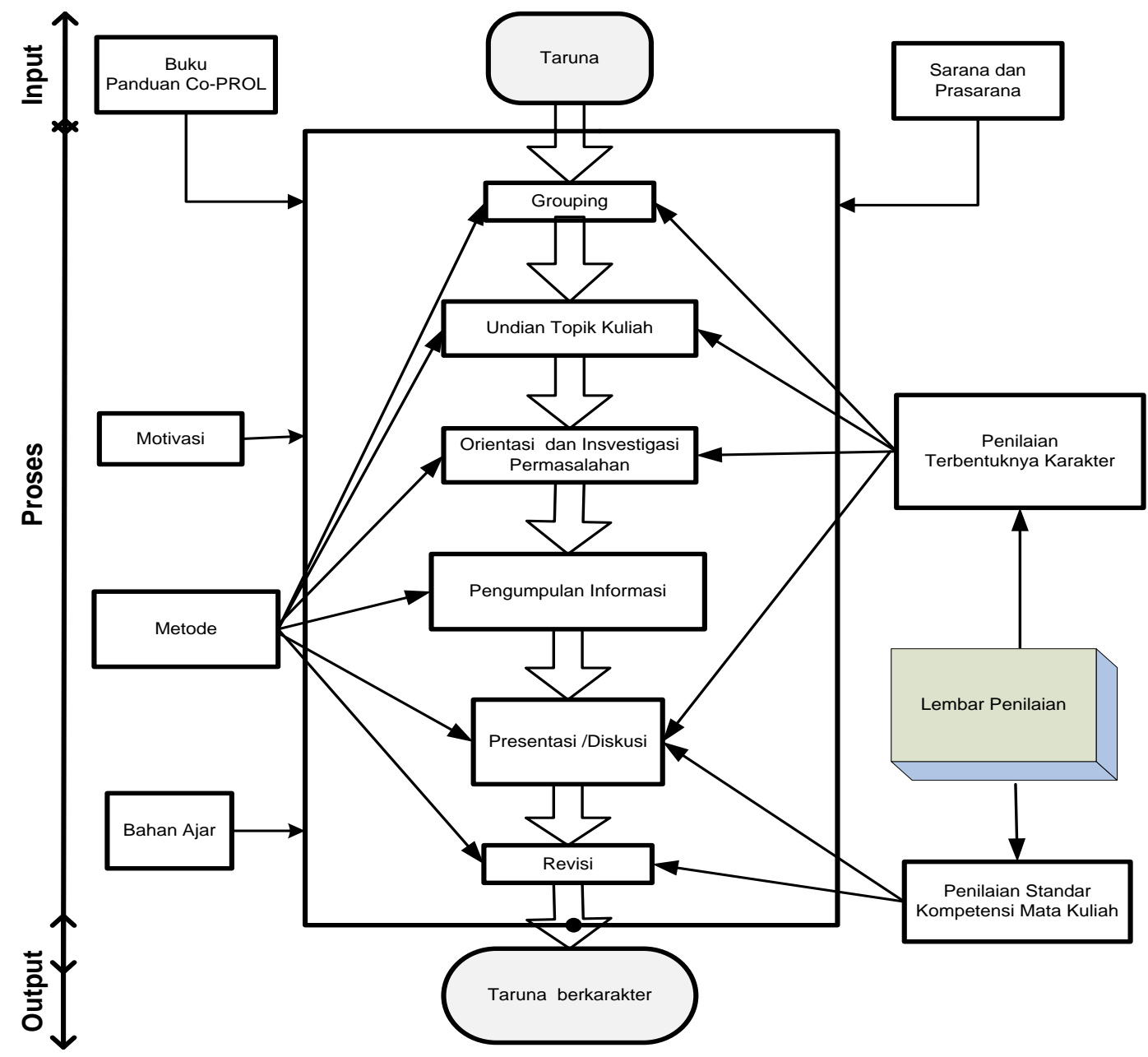

Gambar 1. Model Co-Prol Pertama

Keterangan:

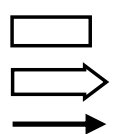

$=$ komponen model pengembangan dalam penelitian ini

$=$ urutan proses

= dukungan sumberdaya 


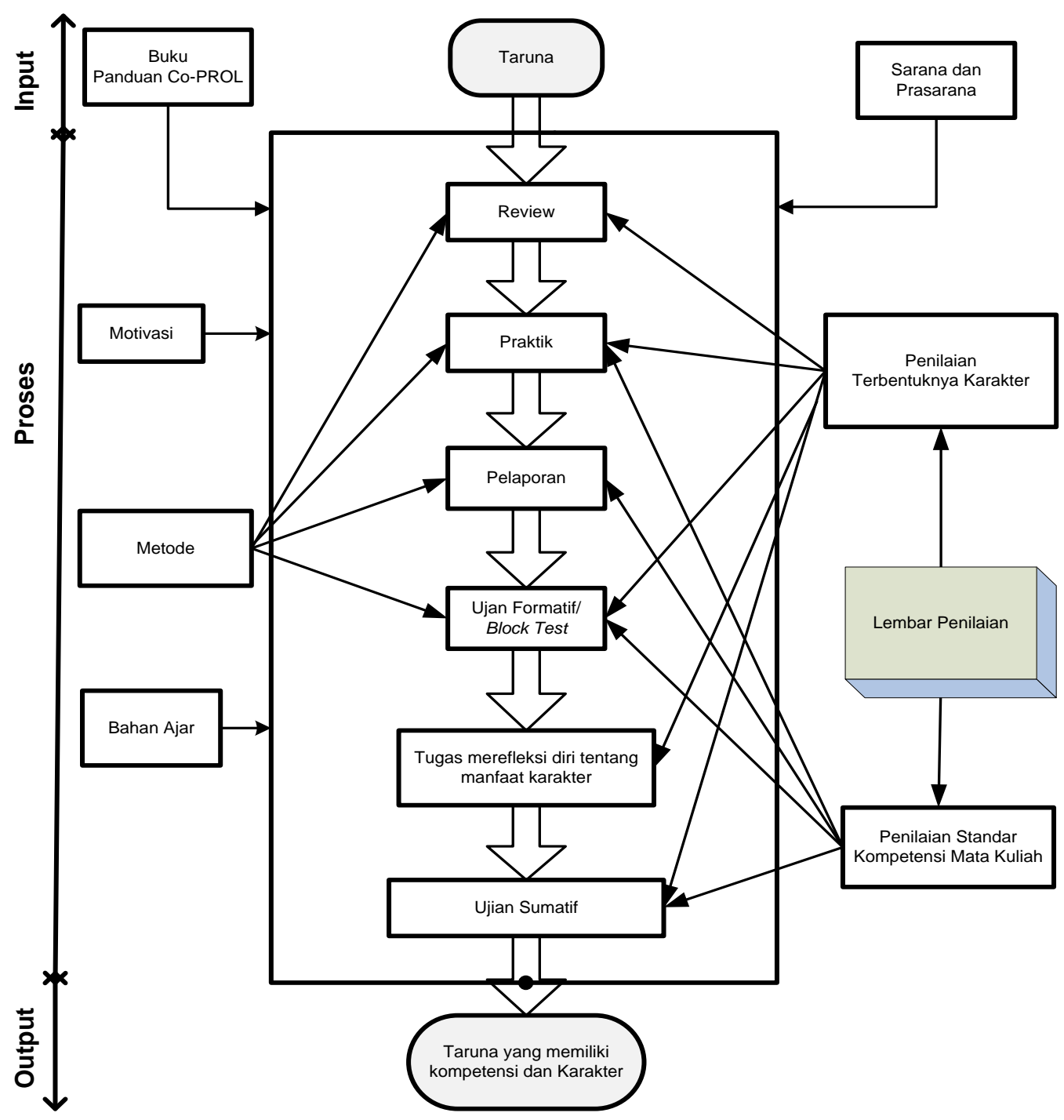

Gambar 2. Model Co-Prol Kedua

Keterangan:

$\begin{array}{ll}\square & =\text { komponen model pengembangan dalam penelitian ini } \\ & =\text { urutan proses } \\ & =\text { dukungan sumberdaya }\end{array}$

\section{Tahap Validasi Model}

Kegiatan validasi dilakanakan dengan dua tahap kegiatan. Pertama dilakukan validasi internal dengan metode focused group discussion (FGD) dan expert judgement atau expert review, dan kegiatan kedua dilakukan validasi eksternal melalui uji coba dengan metode eksperimen. Kemudian dari dua tahap validasi model tersebut dapat dijelaskan sebagai berikut.

Kegiatan FGD dilakukan untuk memperoleh pertimbangan dan kelayakan model oleh pengguna. Peserta FGD diikuti oleh 10 orang, yang terdiri dari dosen Teknika Program D-III Akademi Maritim Yogyakarta, Sekolah Tinggi Maritim dan Transport (STIMART)-AMNI Semarang baik dosen tetap pada prodi teknika maupun dosen pengampu mata kuliah MPU. Setelah pelaksanakan FGD terdapat beberapa perbaikan sebagai berikut: (1) pembagian kelompok secara heterogen berdasarkan nilai akhir MPU-I semester sebelumnya; (2) pemilihan kelas secara random, (3) pengambilan subjek uji coba dilakukan secara random dari kelompok yang beranggotakan 4 taruna diambil 2 taruna dan kelompok yang beranggotakan 3taruna diambil 1 taruna, 
(4) block test dilakukan dua kali sesuai dengan jumlah putaran praktik; (5) menyediakan dua unit peralatan praktik sesuai sesuai dengan topik, (6) jumlah observer 3 orang terdiri dari 1 dosen pengampu dan 2 orang independent; dan (7) pelaksanaan coaching antarobserver dilakukan sebelum dan sesudah pelaksanaan uji coba.

Selanjunya untuk memperoleh validitas model dan buku panduan, peneliti meminta pertimbangan (validasi) kepada ahli. Para ahli yang dimintai pertimbangan terdiri dari tiga orang pakar. Seorang ahli tentang karakter, seorang ahli pendidikan vokasi, dan satu orang sebagai ahli instrument penelitian pendidikan. Adapun hasil validasi dari para ahli terdapat beberapa perbaikan sebagai berikut: (1) penambahan nilai karakter target pada kompetensi dasar; (2) dalam RPP ditambah kolom alokasi waktu; (3) penambahan deskripsi kreteria penilaian (rubrik); (4) penambahan formula nilai akhir untuk teori dan praktik; (5) Perubahan pada bagan prosedur model Co-Prol dosen sebagai pelaku menyampaikan informasi tentang tujuan pembelajaran, bukan taruna; dan (6) revisi penggunaan ejaan sesuai dengan EYD. Hasil validasi internal ini menghasilkan perbaikan-perbaikan dan penyemburnaan rancangan model, kemudian dilanjutkan dengan uji coba.

Uji coba dilakukan menggunakan acuan action plan yang telah disusun dalam Buku Panduan Co-Prol. Hasil uji coba yang dilaksanakan dalam 2 (dua) lokasi yakni: (1) AMY, dan (2) STIMART-AMNI Semarang, masingmasing selama enam belas kali pertemuan. Data hasil pelaksanaan uji coba dibagi dalam lima tahap kelompok pertemuan yaitu; (1) kelompok pertemuan pertama, (2) kelompok pertemuan kedua sampai kelima, (3) kelompok pertemuan keenam sampai kesepuluh, (4) kelompok pertemuan kesebelas sampai kelima belas, dan (5) kelompok pertemuan keenambelas.

Pada kegiatan uji coba pertemuan pertama didapatkan skor hasil amatan dari setiap nilai karakter pelaut,seperti ditunjukkan pada Tabel 1. Dari data terlihat bahwa nilai rerata amatan nilai karakter $(1,10)$ angka ini menunjukkan bahwa nilai kelima karakter taruna masih belum terlihat. Hal ini masih dalam kewajaran karena pertemuan awal taruna dalam mengikuti perkuliahan masih banyak mendengarkan dan bertanya pada materi yang belum jelas, sekaligus kondisi ini dimanfaatkan oleh observer untuk mengenali taruna sambil melakukan pengamatan implementasi karakter pelaut yang sedang dijelaskan.

Tabel 1. .Skor Hasil Amatan Nilai Target Pendidikan Karakter Pelaut Pertemuan Pertama (O1) AMY dan STIMART-AMNI

\begin{tabular}{clc}
\hline No & Aspek Karakter & $\begin{array}{c}\text { Skor pada } \\
\text { Pertemuan Pertama(O1) }\end{array}$ \\
\hline 1 & Tanggung Jawab & 1,24 \\
2 & Kepercayaan Diri & 1,05 \\
3 & Etos Kerja & 1,09 \\
4 & Pemecahan Masalah & 1,02 \\
5 & Kerja Sama & 1,12 \\
& Rerata & 1,10 \\
\hline
\end{tabular}

Skor hasil amatan tahap kedua atau pertemuan kedua sampai dengan kelima didapatkan skor hasil amatan dari setiap nilai karakter pelaut,sepertiyang ditampilkan pada Tabel 2.

Tabel 2. Skor Hasil Amatan Nilai Target Karakter Pelaut Pertemuan Kedua s.d. Kelima.

\begin{tabular}{llcccc}
\hline \multirow{2}{*}{ No } & \multirow{2}{*}{ Aspek Karakter } & \multicolumn{5}{c}{ Skor pada Pertemuan } \\
& & 2 & 3 & 4 & 5 \\
\hline 1 & Tanggung Jawab & 1,60 & 1,86 & 2,01 & 2,32 \\
2 & Kepercayaan Diri & 1,23 & 1,43 & 1,68 & 1,90 \\
3 & Etos Kerja & 1,46 & 1,79 & 1,98 & 2,19 \\
4 & Pemecahan Masalah & 1,22 & 1,45 & 1,74 & 1,96 \\
5 & Kerja Sama & 1,44 & 1,75 & 1,88 & 2,12 \\
& $\quad$ Rerata & 1,39 & 1,66 & 1,86 & 2,10 \\
\hline
\end{tabular}

Nilai rerata 1,39-1,66-1,86 dari pertemuan kedua sampai dengan pertemuan ke empat menunjukkan bahwa nilai target pendidikan karakter pelaut yang diamati selama empat kali pertemuan masih belum terlihat meskipun trend sudah memperlihatkan ada kenaikan perminggunya. Sementara itu rerata nilai karakter pada minggu kelima 2,10, angka ini mempunyai makna bahwa lima karakter pelaut yang diterapkan pada AMY dan STIMART-AMNI telah mulai berkembang pada taruna, nilai tertinggi dicapai pada karakter tanggung jawab $(2,32)$ dan etos kerja $(2,19)$. Karakter peratanggungjawaban ditandai taruna mulai cenderung mampu mengetahui dan melaksanakan apa yang harus dila- 
kukan sebagaimana diharapkan dalam tujuan pembelajaran. Karakter kepercayaan diri dan pemecahan masalah masih belum terlihat pada kegiatan pembelajaran klasikal ini, observer dalam pengamatan mengalami kesulitan karena aktivitas pembelajaran masih banyak bersifat kelompok.Taruna yang pasif dalam pembelajaran klasikal cenderung kepercayaan diri rendah sehingga dalam ikut memcahkan masalah lemah. Ketua kelompok sudah mengatur semua anggotanya mempunyai peran masing-masing baik saat melaksanakan presentasi maupun pada saat menjadi audience, sehingga dapat membangkitkan kepercayaan diri dan membantu memecahkan permasalahan, sehingga kalau sudah terbiasa maka karakter tersebut dapat terbentuk.

Selanjutnya pengamatan terhadap lima nilai-nilai target pendidikan karakter pelaut dengan tigapuluh indikator seperti pada pertemuan sebelumnya, pada tahap ketiga atau pertemuan keenam sampai dengan kesepuluh ditampilkan pada Tabel 3.

Tabel 3. Skor Hasil Observasi Nilai Target Pendidikan Karakter Pelaut Pertemuan Keenam s.d. Kesepuluh AMY dan STIMARTAMNI

\begin{tabular}{llccccc}
\hline \multirow{2}{*}{ No } & Aspek Karakter & \multicolumn{5}{c}{ Skor pada Pertemuan } \\
& \multicolumn{1}{c}{ pelaut target } & 6 & 7 & 8 & 9 & 10 \\
\hline 1 & Tanggung Jawab & 2,57 & 2,78 & 2,89 & 3,00 & 3,15 \\
2 & Kepercayaan Diri & 2,05 & 2,18 & 2,27 & 2,43 & 2,65 \\
3 & Etos Kerja & 2,38 & 2,63 & 2,78 & 2,90 & 3,00 \\
4 & Pemecahan Masalah & 2,11 & 2,24 & 2,37 & 2,57 & 2,78 \\
5 & Kerja Sama & 2,30 & 2,51 & 2,67 & 2,80 & \\
& $\quad$ Rerata & 2,28 & 2,47 & 2,60 & 2,74 & 2,89 \\
\hline
\end{tabular}

Pertemuan ke-enam sampai dengan pertemuan ke-sembilan menunjukkan nilai rerata karakter yakni 2,28-2,47-2,60-2,74 nilai karakter pelaut target yang diamati selama empat kali pertemuan sudah mulai berkembang pada diri taruna, trend rerata ke-lima karakter memperlihatkan selalu ada kenaikan perminggunya. Sementara itu rerata nilai target pendidikan karakter pelaut pada minggu kesembilan 2,74 angka ini mempunyai makna bahwa lima karakter pelaut target yang diterapkan pada AMY dan STIMART-AMNI telah berkembang pada taruna, nilai tertinggi dicapai pada karakter tanggung jawab $(3,00)$ dan etos kerja $(2,90)$, dengan demikian ke-dua karakter ini sudah mulai membudaya pada diri taruna. Karakter etos kerja sudah mulai membudaya terlihat pada saat melaksanakan praktik taruna sangat bersemangat dan antusias untuk melakukan perawatan dan perbaikan pearalatan, sehingga tidak ada taruna yang menganggur, didukung dengan keinginan untuk dapat dapat memecahkan problem dalam perawatan tersebut. Karakter kerja sama juga meningkat seiring dengan kegiatan praktik yang sangat membutuhkan kerja sama dalam kelompok, sehingga dapat saling memberi masukan terhadap permasalahan yang ditemukan. Dosen sebagai fasilitor mengarahkan jika terjadi deadlock pada diskusi yang dilakukan taruna.

Karakter percaya diri dan pemecahan masalah sampai dengan minggu kesembilan masih dalam tahap berkembang, hal ini memperlihatkan bahwa taruna dalam aktivitas praktiknya belum sepenuhnya percaya pada diri sendiri terhadap kemampuan dan kecakapannya, ditandai dengan masih seringnya bertanya dengan teman-temanya. Karakter pemecahan masalah dalam implementasinya masih lemah karena baru tahap berkembang dengan angka $(2,57)$, taruna terlihat masih membutuhkan waktu lama dalam menemukan permasalahan dan solusi dalam proses perawatan peralatan.Pada kelompok uji coba lapangan pertemuan kesebelas sampai kelimabelas diperoleh skor hasil amatan perkembangan nilai karakter pelaut yang dihasilkan ditunjukkan pada Tabel. 4.

Tabel 4. Skor Hasil Observasi Nilai- Nilai Target Pendidikan Karakter Pelaut Pertemuan Kesebelas s.d. KelimabelasAMY dan STIMART- AMNI

\begin{tabular}{llccccc}
\hline \multirow{2}{*}{ No } & Aspek Karakter & \multicolumn{5}{c}{ Skor pada Pertemuan } \\
& Pelaut Target & 11 & 12 & 13 & 14 & 15 \\
\hline 1 & Tanggung Jawab & 3,33 & 3,58 & 3,81 & 3,94 & 3,99 \\
2 & Kepercayaan Diri & 2,86 & 2,95 & 3,02 & 3,15 & 3,39 \\
3 & Etos Kerja & 3,09 & 3,23 & 3,47 & 3,74 & 3,90 \\
4 & Pemecahan Masalah & 2,93 & 3,00 & 3,06 & 3,22 & 3,51 \\
5 & Kerja Sama & 3,01 & 3,11 & 3,28 & 3,49 & \\
& $\quad$ Rerata & 3,04 & 3,17 & 3,33 & 3,51 & 3,70 \\
\hline
\end{tabular}

Pertemuan kelimabelas merupakan kegiatan pembelajaran block test II, yang bertujuan untuk mengetahui kemampuan kom- 
petensi taruna secara individu dalam penanganan perawatan dan perbaikkan system bahan bakar pada mesin diesel kapal. Dalam block test II nilai karakter kerja sama tidak diamati oleh observer karena block test merupakan ujian sehingga tidak ada kerja sama dengan teman sekelompok maupun sekelas.

Pertemuan kesebelas sampai keempatbelas memperlihatkan nilai rerata karakter: 3,04-3,17-3,33-3,51 nilai karakter yang diamati selama empat kali pertemuan sudah membudaya pada diri taruna, trend rerata kelima karakter pelaut target menunjukkan selalu meningkat perminggunya. Sementara itu rerata nilai karakter pada minggu keempatbelas 3,51 angka ini mempunyai makna bahwa lima karakter yang diterapkan pada AMY dan STIMART-AMNI telah membudaya pada diri taruna. Karakter percaya diri, pemecahan masalah, kerja sama sampai dengan minggu keempatbelas sudah dalam tahap mulai membudaya, meskipun nilai amatan masih lebih rendah dibandingkan dengan karakter tanggung jawab dan karakter etos kerja.

Pada kelompok pertemuan terakhir perkembangan kelima nilai target karakter pelaut diperlihatkan pada Tabel 5.

Tabel 5. Skor Hasil Amatan Nilai Target Pendidikan Karakter Pelaut Pertemuan Keenambelas (O2)

\begin{tabular}{clc}
\hline No & Aspek Karakter & $\begin{array}{c}\text { Skor pada Pertemuan ke- } \\
\text { enambelas (O2) }\end{array}$ \\
\hline 1 & Tanggung Jawab & 3,99 \\
2 & Kepercayaan Diri & 3,59 \\
3 & Etos Kerja & 3,94 \\
4 & Pemecahan Masalah & 3,68 \\
5 & Kerja Sama & \\
& $\quad$ Rerata & 3,80 \\
\hline
\end{tabular}

Capaian nilai rerata kelima target karakter pelaut pada pertemuan keenambelas 3,80 hal ini bermakna bahwa kelima target karakter pelaut telah membudaya pada diri taruna. Secara menyeluruh pencapaian kelima karakter tersebut diuraikan sebagai berikut:

\section{Karakter Tanggung Jawab}

Nilai target pendidikan karakter pelaut tanggung jawab dapat dikembangkan dengan baik melalui model pembelajaran pendekatan Co-Prol selama enambelas kali pertemuan. Perkembangannya diamati dan dicatat oleh observer dengan baik untuk kedua institusi AMY dan STIMART-AMNI Semarang. Skor hasil amatan menunjukkan rerata perkembangan nilai karakter tanggung jawab kedua instiusi menunjukan trend meningkat perminggunya, skor hasil amatan berturut-turut sebagai berikut: $1,24 \rightarrow 1,60 \rightarrow 1,86 \rightarrow 2,01$ $\rightarrow 2,32 \rightarrow 2,57 \rightarrow 2,78 \rightarrow 2,89 \rightarrow 3,00 \rightarrow$ $3,15 \rightarrow 3,33 \rightarrow 3,58 \rightarrow 3,81 \rightarrow 3,94 \rightarrow 3,99$ $\rightarrow 3,99$. Hasil amatan ini menunjukkan bahwa pada pertemuan pertama sampai dengan pertemuan keempat nilai karakter tanggung jawab sudah terlihat pada diri taruna, untuk tahap berkembang terlihat pada pertemuan kelima sampai pertemuan kesembilan. Sementara itu nilai karakter tanggung jawab mulai membudaya pada pertemuan kesepuluh, dan pada pertemuan kelima belas dan keenambelas dapat dinyatakan nilai karakter pelaut tanggung jawab menuju ke membudaya penuh dan menjadi kebiasaan pada diri taruna. Trend peningkatan perkembangan nilai karakter pelaut tanggung jawab dapat ditampilkan pada bentuk grafik sebagaimana ditunjukkan pada Gambar 3.

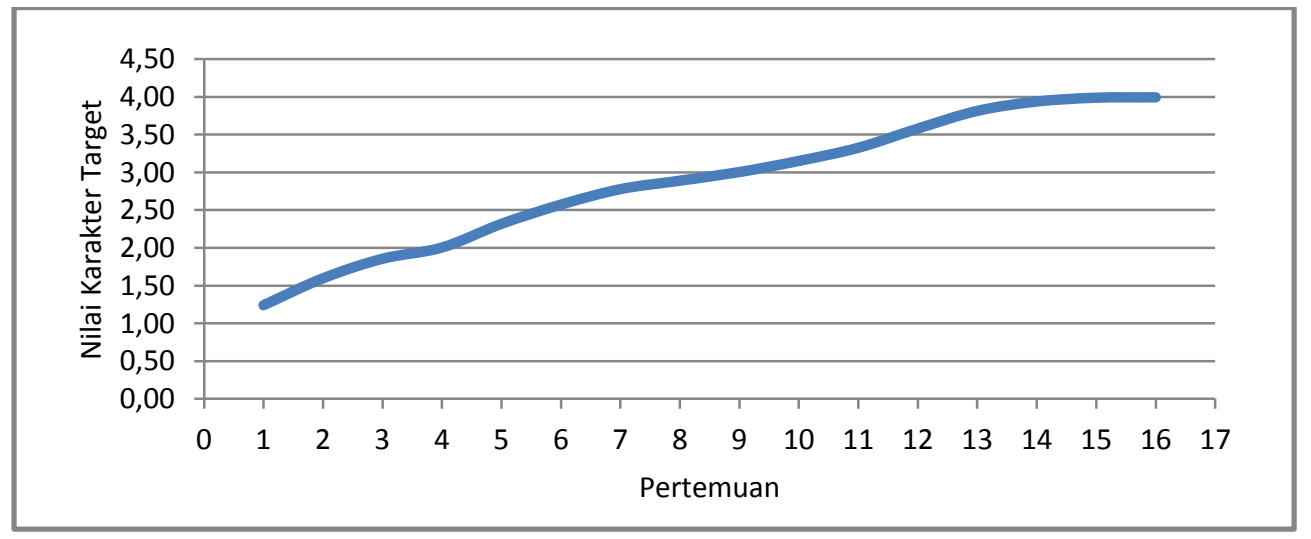

Gambar 3. Grafik Skor Rerata Peningkatan Nilai Target Pendidikan Karakter Pelaut 


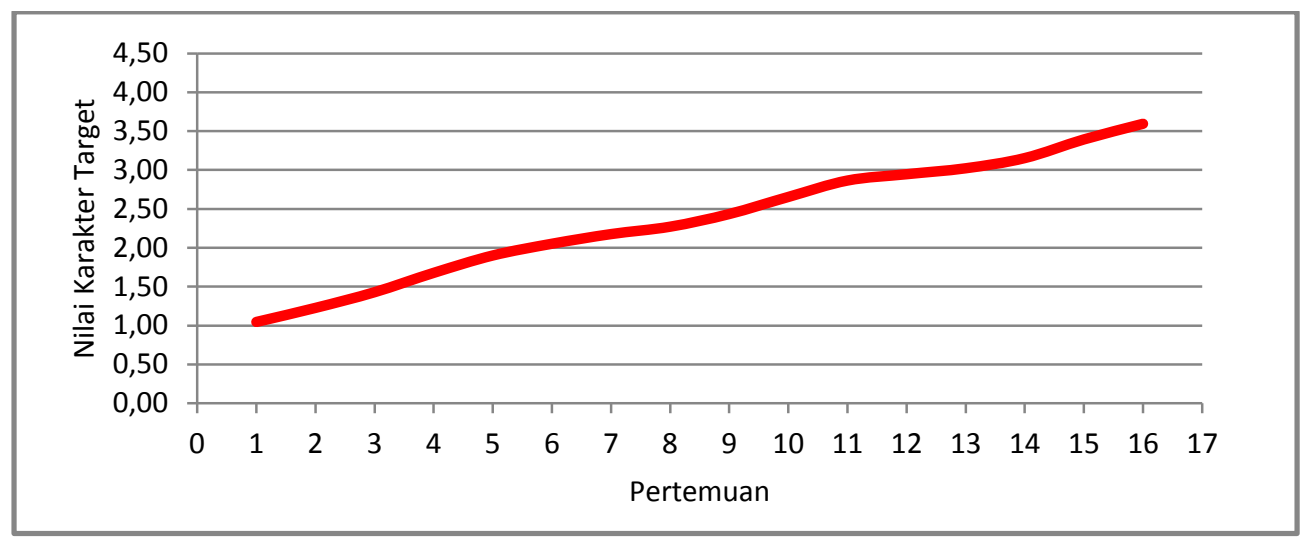

Gambar 4. Grafik Skor Rerata Peningkatan Nilai Target Pendidikan Karakter Pelaut

\section{Tanggung Jawab Pertemuan 1-16 AMY- STIMART-AMNI}

Dengan mencermati Gambar 3. bahwa nilai karakter pelaut tanggung jawab implementasinya dapat terbentuk dengan mudah melalui pendekatan Co-Prol, hal ini ditandai dengan pertemuan pertama sudah langsung terlihat, fenomena ini bisa dimaknai bahwa sesungguhnya taruna sudah memiliki tanggung jawab. Dampak implementasi dari pendekatan model pembelajaran Co-Prol selama enambelas kali pertemuan pada nilai karakter tanggung jawab tampak dari peningkatan skor yang sangat signifikan 1,24 (O1) menjadi 3,99 (O2). Makna dari hasil pengamatan ini adalah bahwa nilai karakter tanggung jawab pada diri taruna dari Mulai Terlihat menuju ke Membudaya, dengan demikian dapat dikatakan bahwa taruna AMY dan STIMART-AMNI Semarang telah tertanam nilai karakter tersebut, sehingga diharapkan mampu membiasakan pada kehidupan sehari-hari dan pada akhirnya sesuai dengan nilai karakter yang dibutuhkan seorang pelaut yang bekerja pada industri pelayaran internasional.

\section{Karakter Kepercayaan Diri}

Perkembangan nilai rerata karakter pelaut kepercayaan diri memiliki trend meningkat perminggunya, ditunjukkan pada skor hasil uji coba lapangan selama enambelas kali pertemuan sebagai berikut: $1,05 \rightarrow 1,23 \rightarrow$ $1,43 \rightarrow 1,68 \rightarrow 1,90 \rightarrow 2,05 \rightarrow 2,18 \rightarrow 2,27$ $\rightarrow 2,43 \rightarrow 2,65 \rightarrow 2,86 \rightarrow 2,95 \rightarrow 3,02 \rightarrow$ $3,15 \rightarrow 3,39 \rightarrow 3,59$. Hasil amatan ini menunjukkan bahwa pada pertemuan keenam nilai karakter target kepercayaan diri baru terlihat pada diri taruna, ini menandakan bahwa ke- percayaan diri implementasinya lebih sulit dibandingkan dengan karakter tanggung jawab. Selanjutnya mencapai tahapan berkembang baru pada pertemuan ketigabelas, sekaligus sebagai awal mulai membudaya. Pertemuan keenambelas perkembangannya menunjukkan skor 3,59, namun dilihat trend perkembangannya selalu meningkat perminggunya meskipun lamban, sehingga belum dapat dinyatakan sepenuhnya karakter kepercayaan diri sudah membudaya atau belum sepenuhnya menjadi kebiasaan pada diri taruna. Trend perkembangan nilai karakter kepercayaan diri dapat ditampilkan pada bentuk grafik sebagaimana pada Gambar 4.

\section{Kepercayaan Diri Pertemuan 1-16 AMY- STIMART-AMNI}

Dampak implementasi dari pendekatan model pembelajaran Co-Prol selama enambelas kali pertemuan pada nilai target karakter percaya diri tampak dari peningkatan nilai yang 1,05 (O1) menjadi 3,59 (O2). Makna dari hasil amatan ini adalah bahwa nilai karakter kepercayaan diri pada diri taruna dari Mulai Terlihat menuju ke Membudaya, dengan demikian dapat dikatakan bahwa taruna AMY dan STIMART-AMNI Semarang telah tertanam nilai karakter kepercayaan diri.

\section{Karakter Etos Kerja}

Nilai target pendidikan karakter pelaut etos kerja yang dikembangkan melalui pendekatan pembelajaran model Co-Prol telah berhasil diimplementasikan dalam enambelas kali pertemuan. Skor hasil amatan perkembangan rerata nilai karakter pelaut etos kerja selama enambelas kali pertemuan berturut- 
turut sebagai berikut: $1,09 \rightarrow 1,46 \rightarrow 1,79 \rightarrow$ $1,98 \rightarrow 2,19 \rightarrow 2,38 \rightarrow 2,63 \rightarrow 2,78 \rightarrow 2,90 \rightarrow$ $3,00 \rightarrow 3,09 \rightarrow 3,23 \rightarrow 3,47 \rightarrow 3,74 \rightarrow 3,90$ $\rightarrow 3,94$. Skor hasil amatan ini menunjukkan bahwa pada pertemuan pertama sampai dengan pertemuan keempat nilai target karakter pelaut etos kerja sudah terlihat pada diri taruna, selanjutnya pada pertemuan kelima mulai berkembang dan mulai membudaya pada pertemuan kesebelas. Karakter pelaut etos kerja telah berhasil menuju membudaya penuh dan menjadi kebiasaan pada diri taruna pada pertemuan kelima belas dan keenambelas meskipun belum seratus persen terimplementasi. Trend peningkatan perkembangan nilai target karakter pelaut etos kerja dapat diperlihatkan pada bentuk grafik sebagaimana ditunjukkan pada Gambar 5 .

Dampak dari implementasi model CoProl selama enambelas kali pertemuan pada nilai karakter etos kerja tampak dari peningkatan skor yang sangat signifikan dari angka 1,09 (O1) menuju 3,94 (O2). Dengan demikian dapat dikatakan bahwa perkembangan nilai etos kerja lebih mudah karena pada pertemuan pertama sudah mulai terlihat. Makna dari angka rerata ini adalah bahwa nilai karakter pelaut etos kerja taruna dari Belum Terlihat menuju ke Membudaya, dengan demikian dapat dikatakan bahwa taruna AMY dan STIMART-AMNI Semarang telah terimplementasikan nilai karakter pelaut etos kerja.

\section{Karakter Pemecahan Masalah}

Observer dalam mengamati aktivitas taruna baik pada waktu uji coba di klas maupun praktik di laboratorium tidak mengalami kesulitan, karena aktivitas pemecahan masalah taruna terlihat pada waktu kelompok pe- nyampaian presentasi, menjawab pertanyaan dalam diskusi, dan pada saat praktik perawatan dan perbaikkan peralatan, serta dalam penyampaian laporan praktik. Peran dosen dalam ini sangat penting karena sebagai fasilitator, sehingga mampu memberikan hasil kerja pemecahan masalah yang telah disampaikan taruna. Berdasarkan skor hasil amatan selama enambelas kali pertemuan diperoleh nilai rerata karakter pelaut pemecahan masalah sebagai berikut: $1,02 \rightarrow 1,22 \rightarrow 1,45$ $\rightarrow 1,74 \rightarrow 1,96 \rightarrow 2,11 \rightarrow 2,24 \rightarrow 2,37 \rightarrow$ $2,57 \rightarrow 2,78 \rightarrow 2,93 \rightarrow 3,00 \rightarrow 3,06 \rightarrow 3,2$ $\rightarrow 3,51 \rightarrow 3,68$. Hasil amatan observer ini memperlihatkan bahwa perkembangan nilai karakter pelaut pemecahan masalah yang diimplementasikan pada taruna lamban dibandingkan dengan karakter target yang lainnya, ditunjukkan pada pertemuan keenam perkembangan baru mencapai terlihat $(2,11)$. Tahap berkembang dicapai pada pertemuan yang keduabelas $(3,00)$ saat taruna melaksanakan praktik sistem bahan bakar di laboratorium. ementara tahapan mulai menuju membudaya pada pertemuan ke-tigabelas sampai dengan pertemuan keenambelas dengan skor baru mencapai $(3,68)$, dengan melihat amatan ini dapat dimaknai bahwa karakter yang dikembangkan melalui pendekatan Co-Prol telah berhasil diimplementasikan pada diri taruna dari Belum Terlihat menuju Membudaya, dan pada Gambar 6 memperlihatkan trend meningkatnya perkembangan nilai karakter pelaut target pemecahan masalah perminggunya. Dengan demikian dampak dari implementasi nilai karakter pelaut target ini memberikan perubahan perilaku taruna sebagai calon pelaut sesuai yang di butuhkan industri pelayaran internasional.

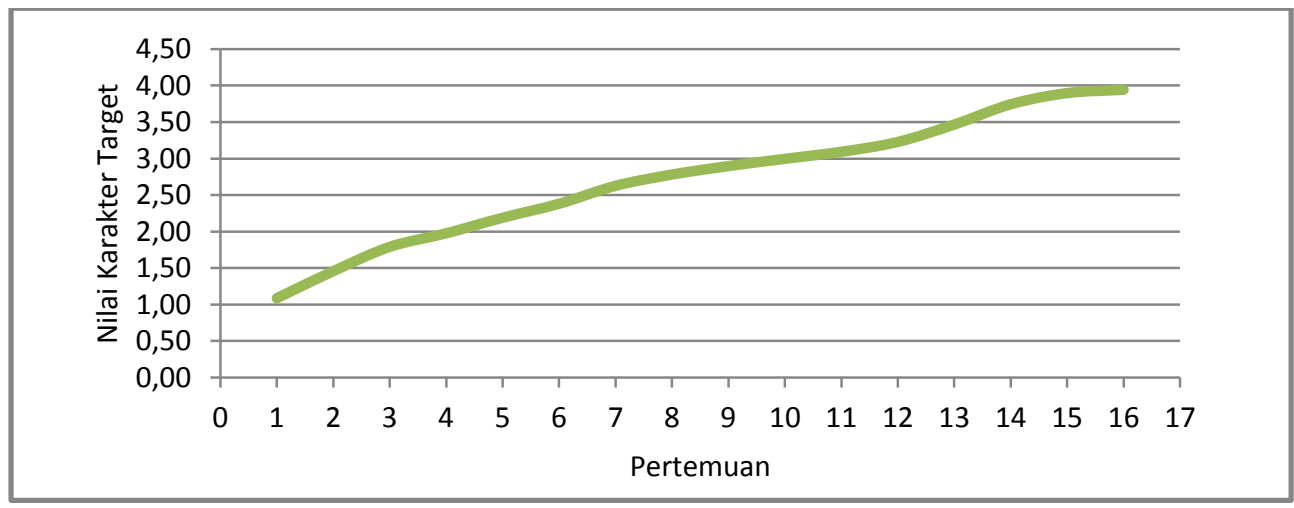

Gambar 5. Grafik Skor Rerata Peningkatan Nilai Target Pendidikan Karakter Pelaut Etos KerjaPertemuan 1-16 AMY-STIMART-AMNI 


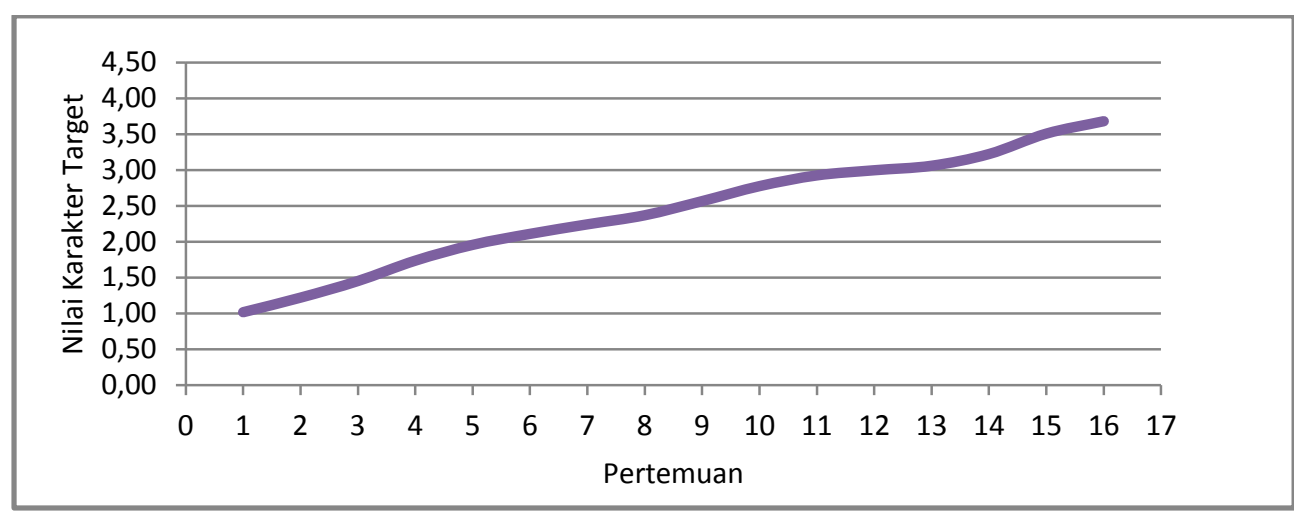

Gambar 6. .Grafik Skor Rerata Peningkatan Nilai Target Pendidikan Karakter Pelaut Pemecahan Masalah Pertemuan 1-16 AMY-STIMART-AMNI

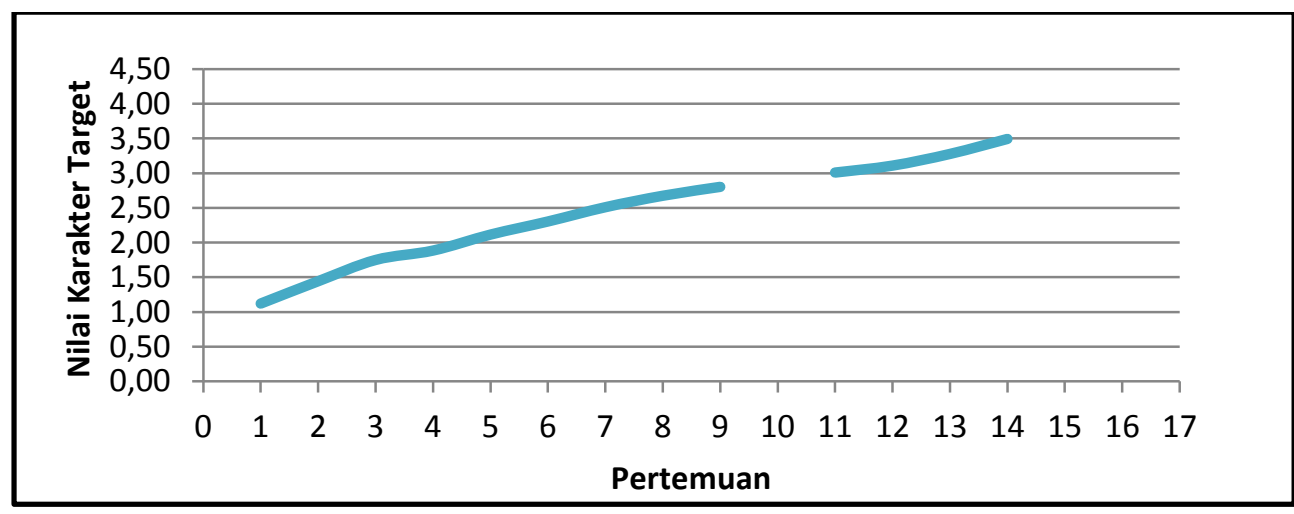

Gambar 7. Grafik Skor Rerata Peningkatan Nilai Target Pendidikan Karakter Pelaut

\section{Karakter Kerja Sama}

Pelaksanaan observasi perkembangan rerata nilai karakter pelaut kerja sama yang dilakukan observer ada perbedaan dengan karakter target sebelumya karena penilaian dilaksanakan hanya dalam tigabelas kali pertemuan. Tiga pertemuan dilakukan ujian melalui block test dan ujian sumatif terhadap taruna, sehingga nilai karakter kerja sama tidak boleh dikembangkan dalam pelaksanaan ujian tersebut. Skor hasil amatan implementasi Co-Prol selama tigabelas kali pertemuan berturut-turut sebagai berikut: $1,12 \rightarrow$ $1,44 \rightarrow 1,75 \rightarrow 1,88 \rightarrow 2,12 \rightarrow 2,30 \rightarrow 2,51$ $\rightarrow 2,67 \rightarrow 2,80 \rightarrow(-) \rightarrow 3,01 \rightarrow 3,11 \rightarrow 3,28$ $\rightarrow 3,49 \rightarrow(-) \rightarrow(-)$. Hasil amatan ini menunjukkan bahwa pada pertemuan pertama telah terlihat nilai karakter pelaut target kerja sama, karena karakter ini mudah untuk dikembangkan, sesuai dengan pengertian sebelumnya bahwa setiap individu cenderung mudah untuk saling kerja sama dalam menyelesaikan suatu tugas. Pertemuan kesepuluh penilaian karakter kosong karena dilaksanakan block test I, sehingga skor nilai karakter sama dengan sebelumnya, selanjutnya penilaian diteruskan pada pertemuan minggu kesebelas sampai dengan minggu kelimabelas, pada tahapan ini perkembangan karakter sudah menuju ke membudaya dengan skor $(3,49)$ meskipun belum optimal. Melihat kondisi ini bahwa trend peningkatan nilai karakter pelaut kerja sama berjalan seiring dengan waktu. Trend peningkatan perkembangan nilai karakter pelaut kerja sama dapat diperlihatkan pada grafik sebagaimana pada Gambar 7 .

\section{Kerja Sama Pertemuan 1-16 AMY- STIMART-AMNI}

Dampak dari implementasi pembelajaran dengan pendekatan model Co-Prol selama tigabelas kali pengamatan pada nilai karakter pelaut kerja sama tampak dari peningkatan skor yang cukup signifikan dari 1,12 (O1) menjadi 3,49 (O2). Makna dari nilai ini adalah bahwa nilai karakter pelaut kerja sama taruna dari Belum Terlihat menuju ke Membudaya, walaupun masih diawal/mulai 
membudaya. Dengan demikian dampak dari implementasi nilai karakter pelaut ini memberikan perubahan perilaku taruna sebagai calon pelaut sesuai yang di butuhkan industri pelayaran internasional.

Keefektifan model Co-Prol dalam mengembangkan nilai target pendidikan karakter pelaut terhadap taruna AMY dan STIMARTAMNI berdasarkan amatan observer dan refleksi diri taruna menunjukan hasil yang efektif. Dengan kata lain skor hasil amatan observer dan refleksi diri taruna menunjukan perkembangan yang meningkat, hal ini ditunjukan dengan capaian implementasi nilai karakter pada kualifikasi membudaya/terbiasa. Hasil rerata refleksi diri taruna dan amatan observer kedua Perguruan Tinggi tersebut ditunjukkan pada Gambar 8.

Berdasarkan data memperlihatkan bahwa skor perkembangan nilai karakter pelaut target sebelum implementasi/pertemuan pertama (O1) memiliki rerata $(2,25)$, ini bermakna bahwa taruna dalam menilai dirinya sendiri lebih tinggi dari penilaian yang dilakukan observer yang hanya mencapai rerata $(1,10)$, namun keduanya masih dalam tahapan belum terlihat/belum terbiasa dalam mengimplementasikan nilai karakter pelaut target tersebut. Sementara itu dalam perkembangan akhir setelah implementasi/ pada pertemuan keenambelas $(\mathrm{O} 2)$ penilaian refleksi diri taruna mencapai skor rerata $(3,66)$ dan amatan observer penilaian mencapai skor rerata $(3,74)$, artinya penilaian observer dengan hasil penilaian taruna ada perbedaan, hal ini tidak berpengaruh terhadap nilai efektifitas model pendekatan Co-Prol, karena keduanya menunjukkan hasil yang signifikan terhadap implementasi nilai karakter target dengan capaian dalam tahapan membudaya/ terbiasa pada diri taruna. Dengan demikian dapat dinyatakan bahwa model pendekatan Co-Prol telah berhasil dan efektif untuk implementasi terhadap nilai karakter pelaut pada kedua Perguruan Tinggi AMY dan STIMART-AMNI Semarang.

\section{SIMPULAN DAN SARAN}

\section{Simpulan}

Berdasarkan seluruh uraian yang disajikan, maka dapat ditarik simpulan sebagai berikut. Pertama, nilai karakter pelaut yang dikembangkan/ditanamkan pada taruna berdasarkan hasil needs assessment di Pertikepel adalah nilai karakter pelaut disiplin.

Kedua, nilai-nilai karakter pelaut yang seharusnya dikembangkan di Pertikepel sesuai kebutuhan industri pelayaran internasional adalah tanggung jawab/responsibility, kepercayaan diri, etos kerja, pemecahan masalah/ problem solving, dan kerja sama/cooperativeness.

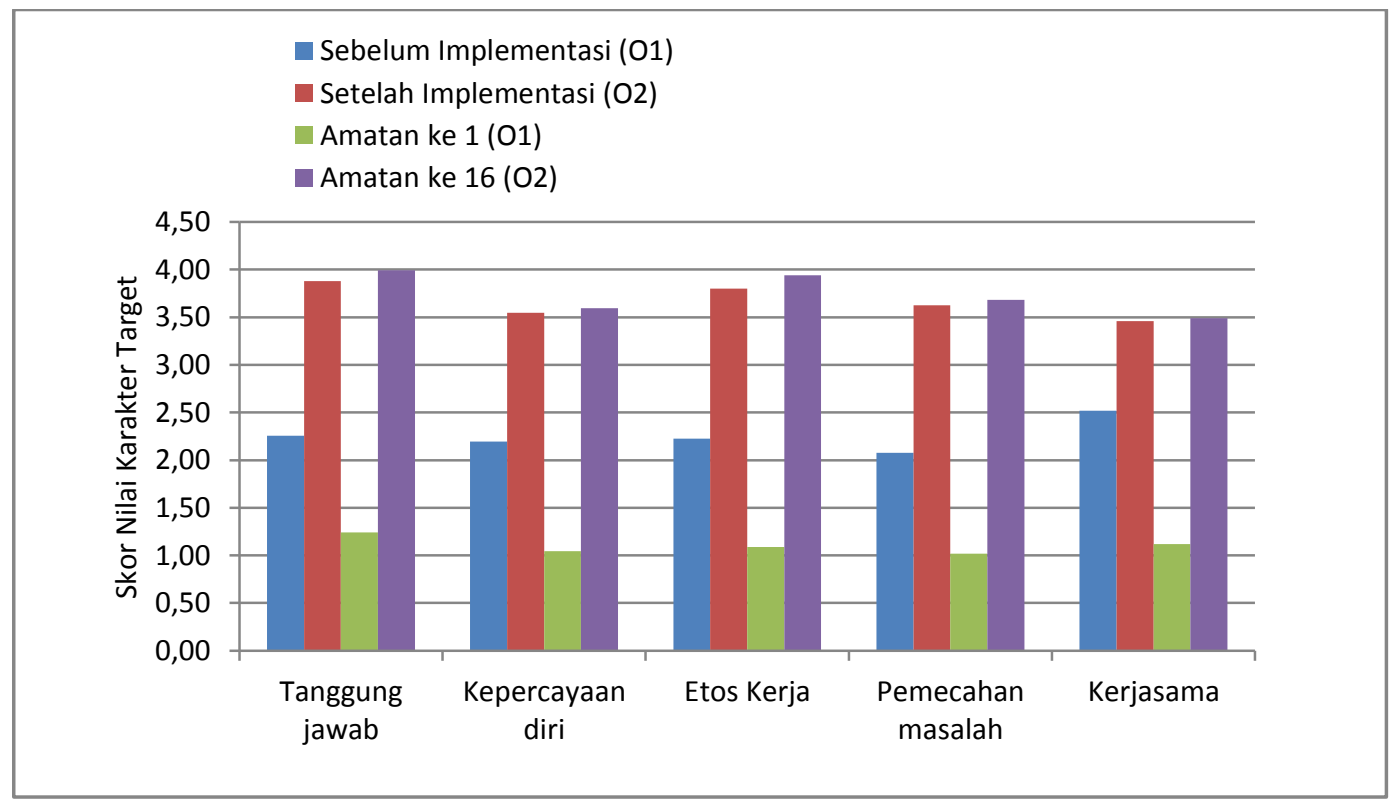

Gambar 8. Pelaut Di AMY dan STIMART-AMNI 
Ketiga, model pembelajaran Co-Prol yang telah dikembangkan melalui implementasi nilai-nilai karakter pada prodi Teknika di AMY dan STIMART-AMNI Semarang, mulai pertemuan pertama sampai dengan pertemuan keenambelas dapat berjalan sesuai dengan tahap-tahap yang telah direncanakan. Hasil analisis menunjukkan model pembelajaran Co-Prol efektif untuk mengembangkan nilai karakter taruna. Keefektifan model terlihat dari perkembangan trend peningkatan nilai karakter taruna per-minggunya. Adapun perkembanganya adalah sebagai berikut: (a) nilai karakter tanggung jawab meningkat dari belum terlihat (pretest $=1,24)$ menuju membudaya penuh (posttest $=3,99$ ); (b) nilai karakter kepercayaan diri meningkat dari belum terlihat (pretest $=1,05)$ berkembang menuju membudaya (posttest 3,59); (c) nilai karakter etos kerja meningkat dari belum terlihat (pretest $=1,09)$ menuju membudaya (posttest 3,94); (d) nilai karakter pemecahan masalah meningkat dari belum terlihat (pretest $=1,02$ ) berkembang menuju membudaya (posttest 3,68 ); dan (e) nilai karakter kerja sama meningkat dari belum terlihat (pretest $=1,12$ ) berkembang menuju membudaya (posttest 3,49). Hasil ini didukung dengan refleksi diri taruna yang menunjukkan bahwa hasil implementasi nilai target pendidikan karakter pelaut linier terhadap hasil dari pengamatan yang dilakukan oleh observer.

\section{Saran}

Berdasarkan simpulan dan keterbatasan penelitian di atas diajukan saran-saran sebagai berikut. Pertama, dosen Pertikepel dalam melaksanakan kegiatan pembelajaran di kelas maupun laboratorium sebaiknya menggunakan model Co-Prol ini sebagai panduan karena terbukti efektif untuk mengimplementasikan nilai-nilai karakter pelaut.

Kedua, keberhasilan implementasi model sangat ditentukan oleh peran dosen, oleh karena itu diperlukan adanya pelatihan bagi dosen yang akan menggunakan model CoProl ini.

Ketiga, penelitian ini baru mengimplementasikan lima nilai karakter pelaut pada model Co-Prol yang sesuai dengan kebutuhan industri pelayaran internasional saat ini, namun bagi pengguna dapat dikembangkan lebih lanjut secara fleksibel sesuai konteksnya.
Keempat, peningkatan kualitas lulusan yang sesuai dengan kebutuhan industri pelayaran internasional, diperlukan peran pengambil kebijakan, khususnya pimpinan Partikepel untuk dapat menindaklanjuti hasil penelitian ini. Kebijakan pimpinan diperlukan, agar pelaksanaan model dapat dilaksanakan secara menyeluruh dan simultan.

Keenam, untuk lebih mengefektifkan pembelajaran nilai-nilai karakter pelaut di kalangan taruna, perlu dilakukan pembiasaan melalui kultur kampus, kegiatan ekstrakurikuler dan didukung dengan pendekatan keteladanan.

\section{DAFTAR PUSTAKA}

Departemen Perhubungan RI. (2000). Peraturan Pemerintah RI Nomor 7, Tahun 2000, tentang Kepelautan.

Elenora. (2009). Prespektif kebutuhan SDM pelayaran sekarang dan masa yang akan datang. Makalah disajikan dalam kuliah umum di AMY.

Gunawan, H. (2012). Pendidikan karakter konsep dan implementasi. Bandung: Alfabeta.

Hergenhahn, B. R. \& Olson, M. H., (2010). Theory of learning (teori belajar). $7^{\text {th }}$ Edition. Jakarta: Kencana.

Internatioal Maritime Organization (IMO). (2011). STCW convention and STCW code: London: IMO.

Isaac, S., \& Michael, W.B. (1981).Handbook in research and evaluation.Second edition. San Diego, California: Edits Publisher.

Majalah Maritim. (Edisi No: 476, 23 Nopember - 3 Desember 2007). Kualitas Pendidikan maritim belum merata. Jakarta: Gamalama Media, 02.

Pemerintah Republik Indonesia. (2010). Kebijakan nasional pembangunan karakter bangsa tahun 2010 - 2025.

Pratama, W. (2010).Evaluasi implementasi QSS berbasis IMO di Akademi Maritim Yogyakarta. Laporan Penelitian. Yogyakarta: UNY.

Rahyubi, H. (2012). Teori-teori belajar dan aplikasi pembelajaran motorik diskripsi dan tinjauan kritis. Bandung: Referens. 
Richey, R.C., \& Klein, J.D. (2009).Design and development research. New York: Routledge

Rusmono. (2012). Strategi pembelajaran dengan problem based learning itu perlu. Bogor: Grahlia Indonesia.

Schunk, D.H. (2012). Learning theories an education prespective, translation from english language edition. Yogyakarta: Pustaka Pelajar.

Yusof, M., et.al, (2011). Cooperative Problem Based Learning: A Practical Model for a Typical Course. IEEE Global Engineering Education Conference (EDUCON), pp 366-373. Universiti Teknologi Malaysia, Johor Bahru Malaysia. Diakses tanggal 11 Maret 2015.

Zuchdi, D.,et.al, (2010). Pendidikan karakter dengan pendekatan komprehensif terintegrasi dalam perkuliahan dan pengembangan kultur universitas. Yogyakarta: UNY Press. 